Chapter 9

\title{
The Impact of Hurricane Debbie (1961) and Hurricane Charley (1986) on Ireland
}

\author{
Kieran R. Hickey and Christina Connolly-Johnston \\ Additional information is available at the end of the chapter \\ http://dx.doi.org/10.5772/54039
}

\section{Introduction}

Ireland has long been in receipt of the tail-end of a small number of Atlantic hurricanes and is the most affected country in Europe by these storms. Although almost never actual hurricanes by the time they reach Ireland, they have still caused loss of life, injuries and extensive damage through high winds, heavy rainfall and storm surges along the coast. Little research has been carried out on these events until recently and their effects have been subsumed into the general mid-latitude storm record [1].

The chapter will investigate and analyse in detail the impact of the worst two hurricane events or tail-ends to affect Ireland over the last 50 years as both storms caused fatalities and injuries and extensive damage across the island of Ireland. In addition Hurricane Debbie in 1961 is the only hurricane to have ever made landfall in Ireland (as a Category 1 event) that is known about, although ongoing research into the historical records of North Atlantic may reveal others, especially in the pre-weather satellite era. Hurricane Charley in 1986 was the tail-end of a hurricane when it hit Ireland, but was considered an extra tropical storm no when it passed by the south coast of Ireland.

In detail this chapter will provide a detailed assessment and analysis of these two events. Firstly it will assess the generation and tracks of the hurricanes. This will be done in the context of Hickey's assessment [2]. The meteorological effects of the two events will be systematically analysed as they passed over the country using hourly data from the relevant meteorological stations around the island of Ireland. The impact of the two events will be assessed using a wide variety of sources including local, regional and national media, local and national government records amongst others. This approach will also help to provide the first meaningful estimates of the financial cost of these two events on Ireland. 


\section{Data sources}

Meteorological information was derived from existing meteorological stations in Ireland as well as satellite imagery of Hurricane Charley in 1986. No such imagery exists for Hurricane Debbie in 1961. Hourly wind data and other parameters were analysed by event.

The information on the impact of events were gleaned from a wide variety of local and national newspaper sources throughout Ireland with special emphasis on the local newspapers in the worst affected areas of the country. As a result of the number of fatalities and the scale of damage both events generated considerable media coverage. The information from these sources was analysed according to type of damage and the exact location where they occurred. The newspapers consulted included the Anglo-Celt, Connacht Tribune, Connaught Telegraph, Irish Independent, Irish Press, Munster Express, Sunday Independent, The Kerryman, Western People and Westmeath Examiner.

\section{Meteorological analysis}

\subsection{Origin and track}

Hurricane Debbie initially formed as a storm west of Africa on the $7^{\text {th }}$ September 1961 and immediately started moving westwards and intensifying and was given hurricane status on the $11^{\text {th }}$ of September and quickly reached Category 3 intensity with maximum wind speeds of $195 \mathrm{~km} / \mathrm{h}$. On the $15^{\text {th }}$ of September the hurricane turned northwards off Cape Verde Islands and then headed northeastwards heading towards Ireland and Europe. It made landfall in Dooega on Achill Island, Co. Mayo off the west coast of Ireland on the $16^{\text {th }}$ of September but passed back out into the Atlantic before tracking along the coast of Scotland and then Norway and finally dissipating over Russia (Fig 1). This hurricane had no effects on the eastern side of the Atlantic which is somewhat unusual but is considered a major contributor to the plane crash on the Cape Verde Islands which cost the lives of 60 people $[3,4]$.

Hurricane Charley is quite different. This hurricane formed in the southeastern Gulf of Mexico on the $13^{\text {th }}$ of August then headed northeastwards through Georgia and South Carolina, USA. It then turned northwards briefly travelling parallel to the eastern seaboard of the USA before again tracking northeastwards across the Atlantic towards Ireland and Europe. The hurricane did not exceed Category 1 status with maximum wind speeds of $130 \mathrm{~km} / \mathrm{h}$ and lowest central pressure of $987 \mathrm{hPa}$. This depression was no longer at hurricane strength when it crossed the southern third of Ireland across Wales and the midlands of the UK before finally dissipating in the North Sea near Denmark on the $25^{\text {th }}$ of August (Fig. 2). In the USA this hurricane caused 5 deaths including 3 in a plane crash and over $\$ 15$ million in damages [5]. 


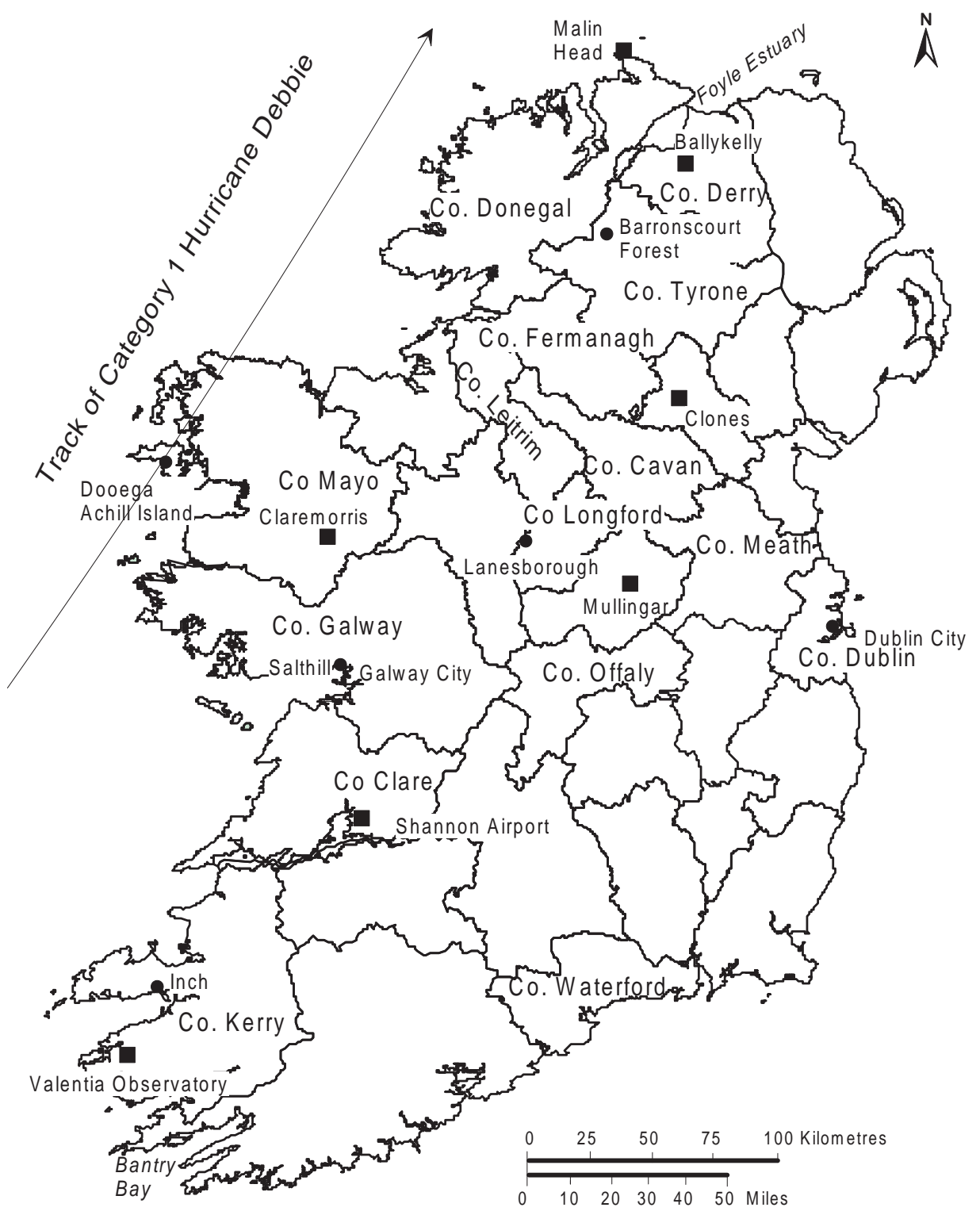

Figure 1. The track of Hurricane Debbie over Ireland, September $16^{\text {th }}, 1961$ 


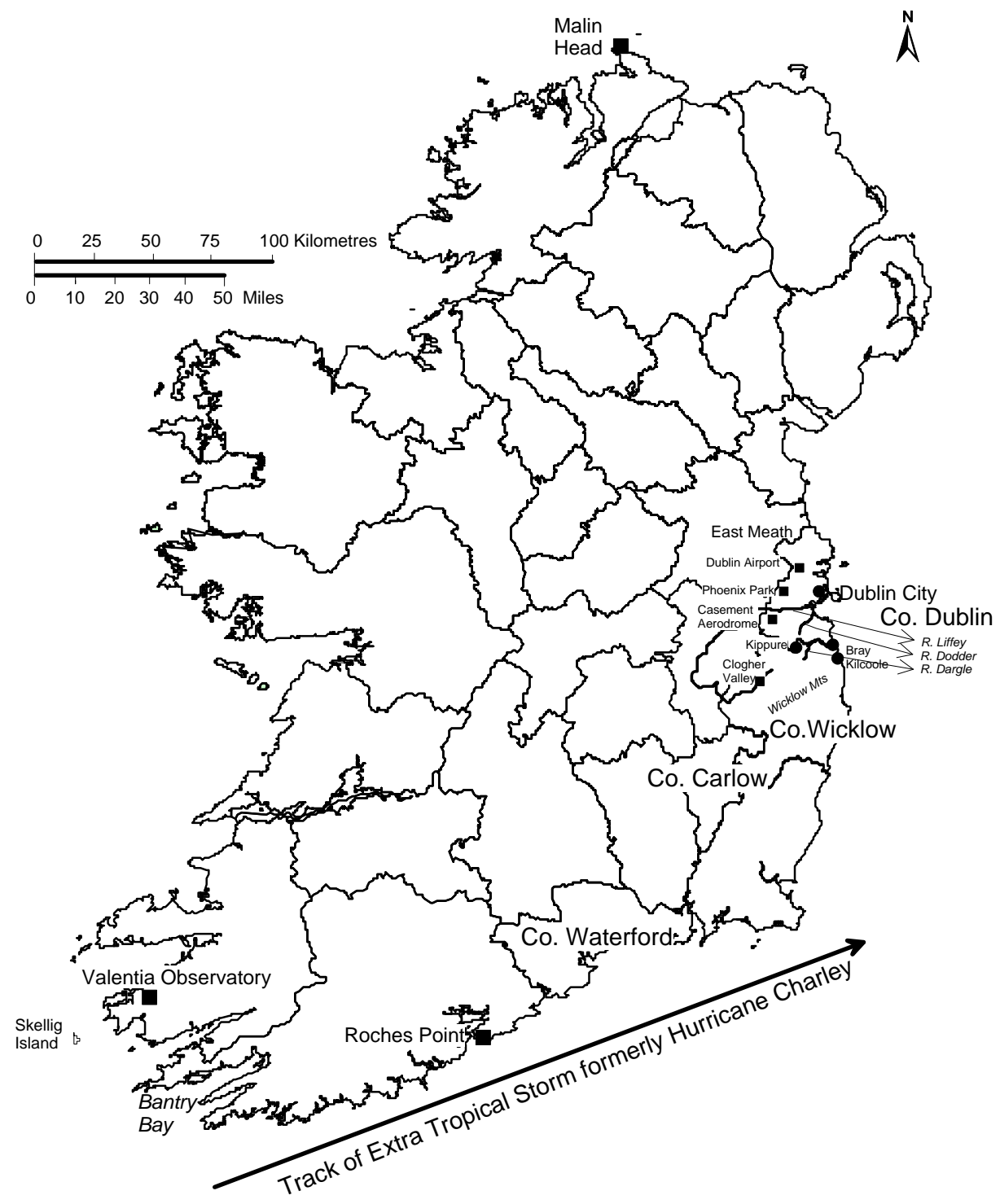

Figure 2. The track of Hurricane Charley over Ireland, 25 ${ }^{\text {th }}$ August 1986.

\subsection{Barometric pressure}

Since 1960 Hickey [6] identified that the lowest Western European barometric pressure reading for any of the tail-end of hurricane events in the survey is $950 \mathrm{hPa}$ which was recorded between Ireland and Scotland and this came from Hurricane Debbie. This was the lowest pressure re- 
corded for this hurricane itself despite the fact that by this stage it was a Category 1 at best. On land the lowest pressures recorded for Debbie were in Co. Mayo at $963 \mathrm{hPa}$ [7]. Hurricane Charley in Ireland was not associated with any significantly low barometric pressure readings.

\section{Wind}

The highest recorded value of any of the events in this survey was from Hurricane Debbie in 1961. At Malin Head on the extreme NW tip of Ireland a gust of $182 \mathrm{~km} / \mathrm{h}$ was recorded. Other exceptional gusts were recorded at Shannon Airport, Rep. of Ireland at $172 \mathrm{~km} / \mathrm{h}$, Ballykelly, Northern Ireland at $171 \mathrm{~km} / \mathrm{h}$, Tiree, Scotland and Snaefell, Isle of Man both at $167 \mathrm{~km} / \mathrm{h}$, Clones, Rep. of Ireland at $161 \mathrm{~km} / \mathrm{h}$, Kyle of Lochalsh, Scotland $159 \mathrm{~km} / \mathrm{h}$ and Mullingar, Rep. of Ireland with $146 \mathrm{~km} / \mathrm{h}[8,9]$. All the above mentioned stations in the Rep. of Ireland and Malin Head and Valentia Observatory were and still are all time record gusts. In addition maximum 10 minute mean wind speed records were set for meteorological stations at Claremorris, Mullingar and Shannon Airport and still stand. These records indicate the exceptional strength of the winds associated with Hurricane Debbie.

In terms of sustained winds the values are obviously lower than that of the gusts but equally important in terms of generating all sorts of damage from the coast moving inland. Unsurprisingly Hurricane Debbie in 1961 also generated the highest sustained values identified $[10,11]$ and the detailed hourly wind values for both Valentia Observatory, SW Ireland and Malin Head, NW Ireland can be outlined. Fig. 3 shows the rising values of sustained hourly wind speed as the hurricane travels offshore along the west coast of Ireland the two aforementioned meteorological stations.

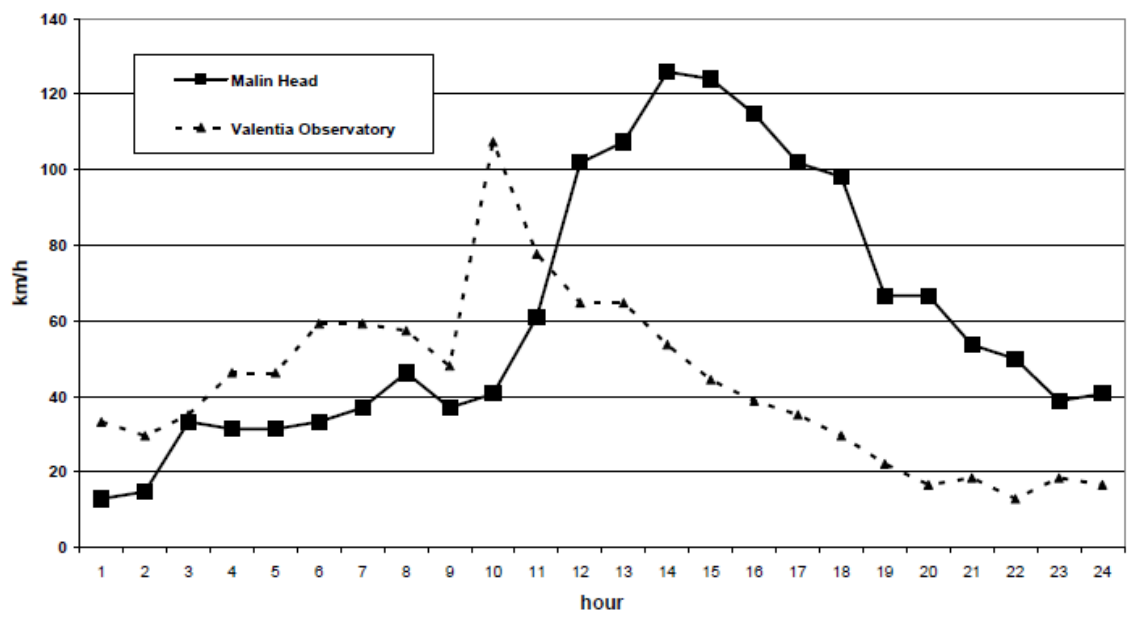

Figure 3. Comparison of the Sustained Hourly Wind Speed of Hurricane Debbie 16th September 1961 for Valentia Observatory and Malin Head Meteorological Stations 
Values at Valentia Observatory are higher than that of Malin Head until noon on the $16^{\text {th }}$ September 1961. Initial values at Valentia Observatory did not exceed $60 \mathrm{~km} / \mathrm{h}$ up to and including the 9am reading, however the maximum value of $107 \mathrm{~km} / \mathrm{h}$ was recorded at $10 \mathrm{am}$ showing a massive elevation of wind speed in a very short time period. For the rest of the day the values of wind speed gradually decline at Valentia Observatory. From 10am onwards wind speeds rapidly rose at Malin Head and reached their maximum value at $2 \mathrm{pm}$ with a sustained value of $126 \mathrm{~km} / \mathrm{h}$, an hour later the wind speed had barely dropped to $124 \mathrm{~km} / \mathrm{h}$, thereafter as the hurricane moved away the wind speeds started to decline but even at $4 \mathrm{pm}$ and $5 \mathrm{pm}$ the wind speed was above $100 \mathrm{~km}$ per hour unlike Valentia Observatory where the peak was relatively brief and at $6 \mathrm{pm}$ the wind had just dropped below $100 \mathrm{~km} / \mathrm{h}$, thereafter the wind speed dropped more rapidly and by midnight was hovering around $40 \mathrm{~km} / \mathrm{h}$, still twice the values being recorded at Valentia Observatory.

The sustained hourly wind data from $25^{\text {th }}$ of August 1986 for Hurricane Charley shows a number of small peaks as well as the main one at Valentia Observatory. Small peaks of wind strength at or above $40 \mathrm{~km} / \mathrm{h}$ occur at $4 \mathrm{am}, 9$ to $11 \mathrm{am}$ and $3 \mathrm{pm}$ to $5 \mathrm{pm}$ (Fig. 4 ). The main peak with winds between 50 and $65 \mathrm{~km} / \mathrm{h}$ occurred between $7 \mathrm{pm}$ and $11 \mathrm{pm}$ thereafter wind speed starts to diminish. Much higher gusts were recorded at Brixham in Devon and Gwennap Head in Cornwall, both in England recording $121 \mathrm{~km} / \mathrm{h}$ and $114 \mathrm{~km} / \mathrm{h}$ respectively. Many southern Irish meteorological stations recorded gusts of between $90 \mathrm{~km} / \mathrm{h}$ and $102 \mathrm{~km} / \mathrm{h}$ but not as strong as England [12]. However the effects of the passing of the hurricane did not cause any significant increase in wind speed in more northerly stations like Malin Head and as such is not included in Fig. 4.

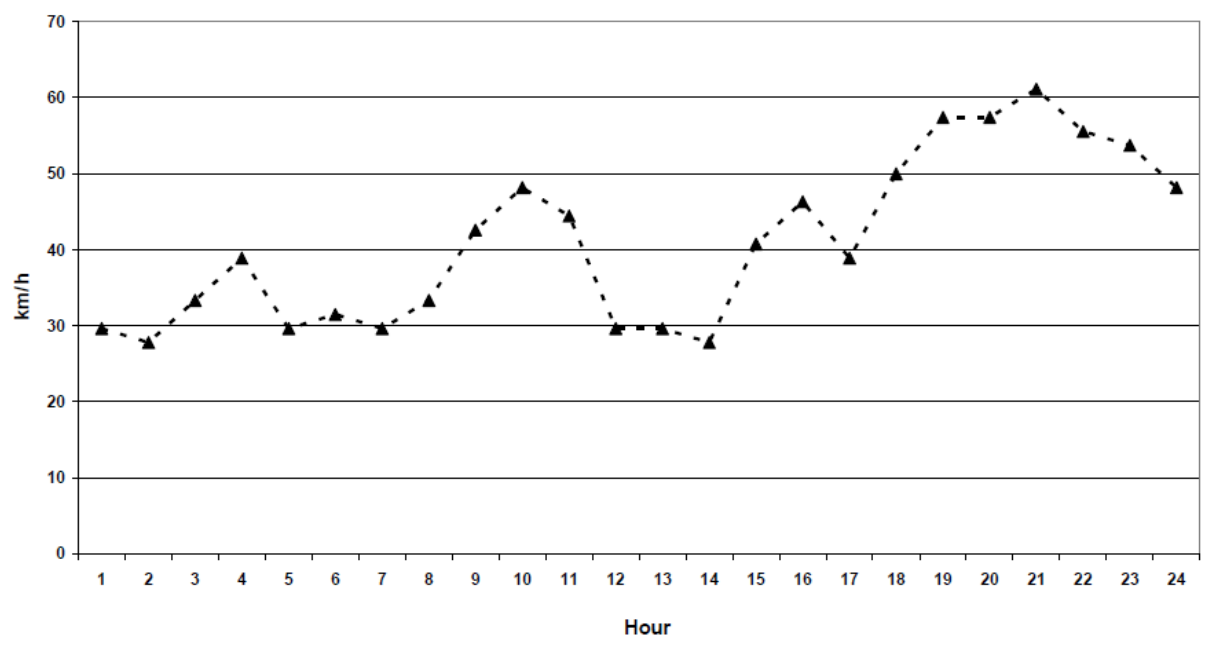

Figure 4. Sustained Hourly Wind Speed of the tail-end of Hurricane Charley on 25th of August 1986 from Valentia Observatory 


\section{Precipitation}

Hurricane Debbie's remnants were responsible for flooding in Ireland, Scotland and Wales but the rainfall amounts although high were by no means exceptional or record breaking [13]. Some of this flooding was associated with the large lakes in the west of Ireland. Fig. 5 shows that there were two main pulses of rainfall at Valentia Observatory coming towards the end of the $16^{\text {th }}$ and the start of the $17^{\text {th }}$ September 1961 peaking at $9 \mathrm{~mm}$ in an hour at $9 \mathrm{pm}$ on the $16^{\text {th }}$. The hourly rainfall at Malin Head shows the second lesser peak at the start of the $17^{\text {th }}$ August but very limited rainfall receipt either before, during or after the hurricane, despite being closer to the landfall site of the hurricane itself.

Hurricane Charley in 1986 produced record high precipitation values for Ireland. In the mountains south of Dublin at Kippure (754m altitude) in excess of $280 \mathrm{~mm}$ was recorded over a 24 hour period, which set a new one day record at altitude for Irish rainfall. However, because of timing errors on the data logger this figure of $280 \mathrm{~mm}$ is viewed as a conservative estimate, the true 24 hour value could be as high as $350 \mathrm{~mm}$ [14]. In addition, the low-lying station at Kilcoole, Co. Wicklow recorded $200 \mathrm{~mm}$ of rainfall, setting a new Irish record for a one day total at low altitude. Additional very high daily rainfall totals were recorded at a number of other meteorological stations including the Phoenix Park, Dublin city $(85.1 \mathrm{~mm})$, Roches Point, Co. Cork (84.4mm) Casement Aerodrome, Co. Dublin $(72.4 \mathrm{~mm})$ and a number of others with values ranging from 50 to $65 \mathrm{~mm}$ [15]. This amount of rainfall unsurprisingly caused significant flooding in Dublin city and also in Bray Co. Wicklow. In parts of Bray water heights reached $2.4 \mathrm{~m}$ and over 450 buildings were affected by the flooding.

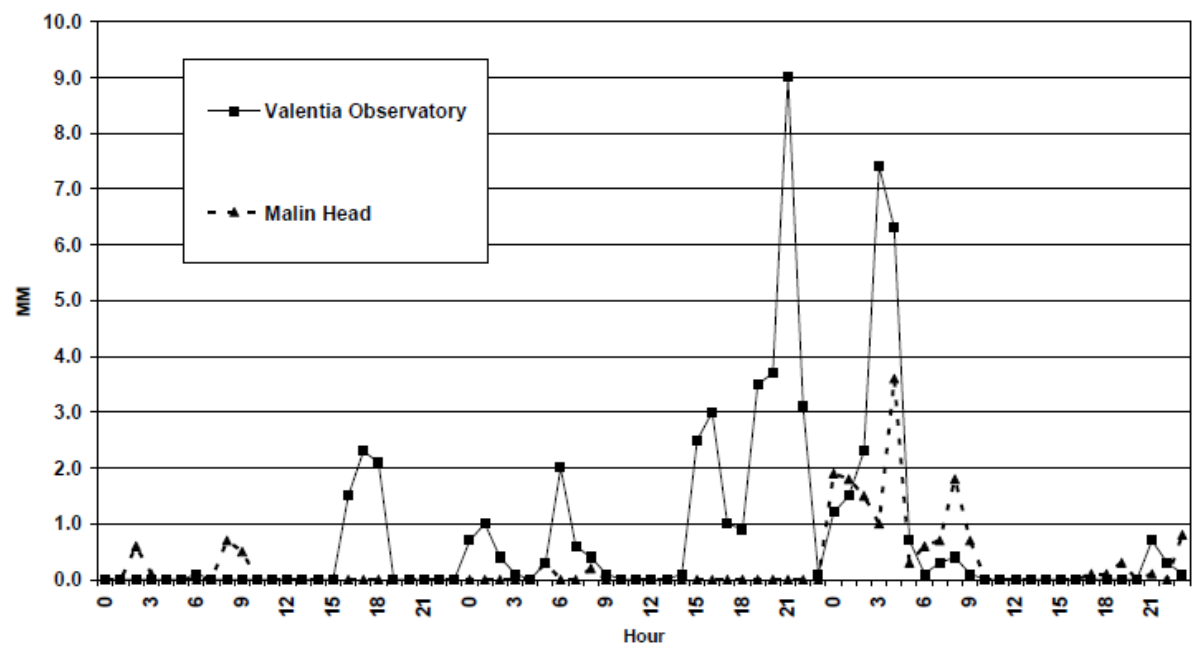

Figure 5. Hourly Rainfall at Valentia Observatory and Malin Head from Hurricane Debbie 15th-17th September 1961 
The hourly rainfall from Valentia Observatory, Dublin Airport and Casement Aerodrome show the heavy rainfall associated with this event (Fig. 6). Valentia Observatory on the west coast records the passage of the event with a midday peak of hourly rainfall receipt on the $25^{\text {th }}$ of August. The two stations on the east coast of Ireland closest to the major flooding record peak hourly rainfall from $4 \mathrm{pm}$ to midnight on the $25^{\text {th }}$ of August with declining rainfall levels from then on apart from a small peak at Dublin Airport at 8am, arguably unrelated to the passage of the tail-end of the hurricane. Casement Aerodrome recorded $9.3 \mathrm{~mm}$ in an hour at $6 \mathrm{pm}$ on the $25^{\text {th }}$ of August the maximum hourly value recorded for any of the three stations. This is the station closest to the locations where the highest daily rainfall totals were recorded, which were in the Wicklow Mts. Valentia Observatory had a maximum value of $7.9 \mathrm{~mm}$ at $1 \mathrm{pm}$ on the $25^{\text {th }}$ and Dublin Airport had a maximum value of $6.8 \mathrm{~mm}$ at $7 \mathrm{pm}$ on the $25^{\text {th }}$ of August 1986.

When the remnants of Hurricane Charley moved on to Wales it also produced excessive rainfall but not quite as high as Dublin. At Aber in Gwynedd in Wales 135mm was recorded over an 18 hour period. Very high daily values were also recorded in England with Walshaw Dean near Halifax having $121 \mathrm{~mm}$ of rainfall and Loggerheads near Wrexham having $109 \mathrm{~mm}$ of rainfall. Many other locations had values near or just exceeding $100 \mathrm{~mm}$ in a day [16].

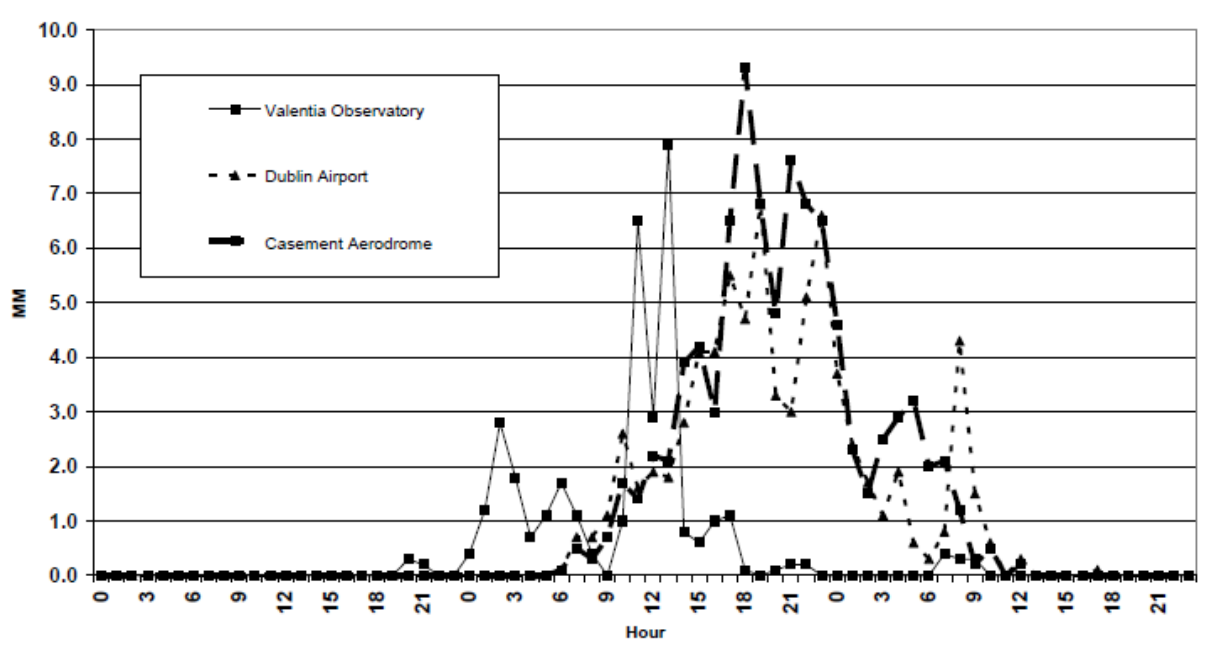

Figure 6. Hourly Rainfall at Valentia Observatory, Dublin Airport and Casement Aerodrome from the tail-end of Hurricane Charley 24th-26th August 1986 
Both events are very different in terms of their origin and track yet both end up crossing Ireland either as a hurricane or extra tropical storm. Both are also significant in an Irish context but for very different reasons, Debbie for record high winds and Charley for record high precipitation. These differences have a big effect on the impacts generated by the two events as will be detailed in the next section.

\section{Impact analysis}

Although the type of impact varies between the two events both produced significant numbers of fatalities and injuries along with considerable economic damage.

\section{Fatalities and injuries}

Aside from the loss of 60 lives in a plane crash on the Cape Verde Islands Hurricane Debbie is directly responsible for the deaths of at least 17 people in Ireland. A systematic search of local and regional newspapers across Ireland was used to generate this figure which is higher than any previous published number $[17,18,19]$. In the worst incident four members of the one family including a one week old being taken home from hospital were killed in Co. Cavan when a tree fell on their car (Fig.1). Tree falls or driving into fallen trees were responsible for another eight deaths in eight separate incidents, three of which occurred in Co. Tyrone, Northern Ireland with one each in Cos. Donegal, Dublin, Longford, Meath and Offaly all in the Rep. of Ireland. Three fatalities occurred as a result of collapsing walls and roofs, one each in Co. Fermanagh in Northern Ireland and Dublin city and Co. Meath in the Rep. of Ireland. In addition a five year old lost his life when he was blown into a stream in Co. Fermanagh, Northern Ireland and another person drowned as a small boat capsized in Co. Derry. A large number of people suffered injuries of which at least seven of these were considered serious. The main causes of these injuries were to do with fallen trees, roofs and walls and flying debris such as roof slates.

As well as the five fatalities in the USA the weather remnants of Hurricane Charley in August 1986 caused an additional 11 fatalities in Europe, six in Ireland and five in England. Most of these fatalities were as a result of drowning in flooded rivers or being trapped in flood waters. Two of the Irish fatalities resulted from drowning incidents in the Dublin area and one of the Irish fatalities occurred as a result of drowning on a canoeing trip in Co. Carlow, Rep. of Ireland (Fig 2). At least one other death is confirmed in the newspapers but with little detail and details on the other two fatalities remain very sketchy at best. The figure of six fatalities for this event has been in all the limited published literature and it is surprising that only three or four definitive fatalities can be identified for this event using modern search methods. The five fatalities in England also resulted mainly from drowning incidents. Very few people sustained injuries in either Ireland or England. 


\section{Economic damage}

\subsection{Hurricane Debbie}

Virtually no area on the island of Ireland was unaffected by the impact of Hurricane Debbie, but the worst affected areas were Cos. Mayo and Galway (Fig 1). Tens of thousands of houses and other structures including churches suffered significant structural damage varying from complete destruction to roof loss to minor damage including broken windows. Much damage was done to walls, sheds and other infrastructure. Caravan parks along the west coast were particularly badly affected with some caravans being moved up to 150 metres and many others being completely destroyed. Roads and other transport routes were blocked as a result of falling trees and electricity and telephone cables. There were extensive power outages with some areas being without power for up to four days as well as extensive disruption to transport including shipping on the Irish Sea.

There was significant damage done to the agricultural sector with the hurricane coming at one of the busiest times of the year. There was widespread damage to barns, sheds and outhouses and other agricultural buildings. In addition unharvested wheat and oats were beaten down in the fields where they stood to such an extent that it is estimated that up to a third of the crop had been lost nationally. Part of the hay crop was blown away if harvested and still uncollected in the fields. The severity of the wind can be seen by the fact that as far as $20 \mathrm{~km}$ inland all plant life withered and died in a matter of minutes as sea spray laden with salt was carried landward by the wind. A similar effect was recorded for the $6^{\text {th }}$ January 1839 storm [20]. There was extensive damage to forestry all across the Ireland. Total losses were of the order of $2 \%$ of all trees in commercial plantations on the island of Ireland but with some forests these losses were up to $24 \%$ [21]. The worst affected plantation was Baronscourt Forest in Co. Tyrone where around 300,000 mature trees were blown down. Other major losses occurred in Cos. Derry, Fermanagh, Leitrim, Galway and Clare. The force of the wind damaged many native trees throughout the country by removal of branches, leaves and shoots. This damage included a large number of sweet cherry trees at a farm in Co. Waterford [22]. Fallen trees and blown debris also killed many farm animals including cattle.

There was extensive damage to shipping along the south, west and north coasts especially at Bantry Bay, Co. Cork and the Foyle Estuary between Cos. Donegal and Derry. A very rare storm-induced tidal bore was recorded as having taken place on the Shannon river near Lanesboro, Co. Longford when the level of the river rose by $1.35 \mathrm{~m}$ as the hurricane winds blew water upstream. This reverse flow carried many small boats upstream and onto the river banks leaving them high and dry when the wind changed direction and the river dropped almost equally as suddenly.

Very little coastal flooding was reported with the exception of Salthill, Galway city which experienced early morning severe tidal flooding. There is some evidence of small scale coastal erosion in parts of Ireland including some significant shoreline recession at Inch, Co. Kerry. However, most of the coasts were not affected due to the nature of the winds being directed obliquely or offshore and the fact that the peak winds did not coincide with high 
tide explains this outcome [23]. On the Lancashire coast of England and the Isle of Man extensive sand storms were recorded with significant deposits of sand inland but there are no records of this occurring in Ireland [24].

It is quite difficult to estimate the cost of Hurricane Debbie but based on the few figures that are available and the scale of the structural damage to properties and infrastructure, the widespread devastation of forestry plantations and the damage to the agricultural sector a figure in 1961 terms of between $\$ 40$ million and $\$ 50$ million would not be unrealistic.

\subsection{Hurricane Charley}

Hurricane Charley mostly affected the southern half of Ireland especially on the east coast with Cos. Dublin and Wicklow being particularly affected (Fig. 2). However, unlike Debbie most of the damage associated with this event was to do with flooding as a result of the exceptional rainfall. Particularly badly affected were parts of south Dublin city with 400 houses flooded and Bray Co. Wicklow where over a thousand residents had to be evacuated as flood waters breached the banks of the River Dargle [25]. Roads, bridges and property were extensively flooded throughout much of the southern and southeastern part of Ireland. Additional flooding was caused by the River Dodder in Dublin city bursting its banks causing significant damage mostly to private dwellings. The Dodder rises in the Dublin Mountains at an altitude of $751 \mathrm{~m}$ OD and as such is vulnerable to flash flooding caused by high mountain rainfall as was the case during Hurricane Charley [26]. The return period of this flood event on the Dodder was estimated to be in excess of 100 years [27]. This was partly based on the recorded maximum output of the Lower Bohernabreena Reservoir on the river. $91.1(\mathrm{~m} 3 / \mathrm{s})$ were recorded the third largest of the records dating back to 1886. The 13th of October 1891 value of $92.2(\mathrm{~m} 3 / \mathrm{s})$ and the $28^{\text {th }}$ August 1905 of 107.8 (m3/s) both events caused very significant flooding, although the areas along the Dodder at this time were much less built-up [28].

Fortunately because of the effects of the River Liffey reservoirs and their effective management, most of Dublin city was unaffected by flooding. Without the reservoirs and the flood management severe flooding would have occurred in Dublin as evidenced by the estimates of peak flow with and estimated without the reservoirs and associated dams. The peak flow downstream of the Leixlip Dam during Hurricane Charley was $170\left(\mathrm{~m}^{3} / \mathrm{s}\right)$ without these structures it was estimated that it discharge would reach $400\left(\mathrm{~m}^{3} / \mathrm{s}\right)$ producing a very different outcome in Dublin city as a result [29]. Parts of East Meath were also considerably affected by flooding, extending the worst flood-affected areas westwards from Dublin city and county [30].

The torrential rain from Charley also triggered three very small scale landslides and one slightly larger one in the Cloghoge Valley in the Wicklow Mts., felling trees and stripping the bark from those left standing as the debris slides tracked through forested areas. The three very small slides involved movement of between 310 and $533 \mathrm{~m}^{3}$ of material whereas the larger slide involved the movement of an estimated $6,578 \mathrm{~m}^{3}$ and covered an area of $12.75 \mathrm{~km}^{2}$. This landslide although much bigger than the other three still only represented $0.14 \%$ of the total catchment, the other three barely reaching $0.01 \%$ of the catchment [31]. 
Wind damage was also recorded across this area with significant damage to power and phone lines partly due to fallen trees. Initially nearly 250,000 people were affected by power failures although this was reduced down to 9,000 after two days of intensive effort. There was extensive disruption to transport both public and private across the country and to ferries in the Irish Sea. Social and sporting fixtures were also cancelled.

Once again the agricultural sector was severely affected by a combination of the heavy rain, leading to flooding and high winds. Cereal production was particularly badly affected with losses of $50 \%$ estimated for Co. Waterford alone. In addition feed, hay and silage supplies also suffered major losses so much so that in many areas in the southern half of the country the early winter housing of livestock had to be implemented as the waterlogged and sodden land could neither provide nor sustain the needs of the animals. Consequentially milk supply and farmers incomes also suffered.

The height of the tail-end of Hurricane Charley also coincided with two high tides generating localized coastal flooding and causing problems for shipping as the pounding waves threw a luxury yacht onto the heavily flooded roadway at Bray seafront in Co. Wicklow. Valentia lifeboat was called out at the peak of the storm to a distress call by a yacht off the Skellig Islands, Co. Kerry.

Again it is impossible to put an exact cost on the damage and destruction caused by the tailend of Hurricane Charley, however some justifiable estimate can be generated by using what few figures are available in 1986 values. Around \$40 million in insurance claims mostly for flooding were made to various insurance companies in Ireland [32]. The Irish Government allocated $\$ 8.65$ million just for road and bridge repairs. However these values do not include the significant losses suffered by the farming sector and also uninsured losses. A true value in excess of $\$ 100$ million and even as high as $\$ 125$ million would not be unjustified for Ireland alone not too mention across the other affected countries in Europe.

\section{Discussion and conclusions}

One of the key results that has emerged from the detailed examination of the impact of Hurricane Debbie and the tail-end of Hurricane Charley is that each had its own unique character. Debbie was very much associated with wind damage and set new wind records for Ireland, some of which still stand today whereas Charley was very much a flood damage event due to the exceptional and again record breaking rainfall. In many respects the two events represent two extremes of the possible types of meteorological effects of the tail-end of a hurricane on Ireland and Europe. Worryingly for Ireland would be the case where an event occurred that contained both exceptionally high winds and exceptionally high rainfall. This could have a devastating impact not just on Ireland but probably on other parts of Europe as well.

However, it is very hard to consider how likely this perfect tail-end/hurricane is to occur for a number of reasons. Firstly, not enough research has been carried out on past Irish storm 
records, in particular there is a need to focus on unusually severe storms that affected Ireland over the last several hundred years during the months of August, September and October and which may have been mistakenly identified as early mid-latitude storms and not ones of tropical origin. Irish storm records go back to the first millennium AD due to the survival of a number of monastic Irish Annals covering this time period up to the middle of the second millennium. These annals record significant weather events including major devastating storms, a few of which might be hurricane in origin.

Secondly, even if potential tail-end of hurricanes or hurricanes themselves were identified, there would be enormous difficulties in categorically proving their tropical origin or at least producing enough evidence to suggest that this was even likely, and in many cases no definitive proof would ever be found particularly events that would predate AD 1800 and especially AD 1700.

Consideration must also be given to rising sea-surface temperatures in the tropics and how this will gradually enlarge the areas lattitudinally where hurricanes could potentially form. This has huge implications for the potential loss of life and damage in tropical areas and this in turn will also have a potentially significant impact on the frequency of the tail-ends of hurricanes and hurricanes themselves reaching and affecting Ireland and Europe. In addition their intensity may be increased as well leading to greater damage and destruction and the potential for more loss of life and injuries. As a result more attention needs to be paid to these events and the frequency with which they affect Western Europe. However, at present modeling of likely future hurricane activity has failed to indicate any significant increase or decrease but it is noted that much research needs to be carried out particularly in dealing with the chaotic nature of the climate system and in the response of the climate to radiative forcing in order to develop much more suitable models for prediction [33].

It is clear that the potential impact of the tail-ends of hurricanes or hurricanes themselves on both Ireland and Europe should not be underestimated as the impacts of Hurricane Debbie and the tail-end of Hurricane Charley on Ireland has shown. Loss of life and injuries can be more severe and greater than that of mid-latitude storms and the potential scale of damage and destruction can be very significant whether through wind damage or flooding or a combination of both.

More recently in 2012 the impact of tail-end of Hurricane Katia on Ireland and Europe with one fatality and extensive damage stretching from Ireland to Russia and the impact of the tail-end of Hurricane Ophelia also in 2012 which brought bad weather to Europe shows that the threat remains ever present. With rising sea surface temperatures in the tropics in the Atlantic the potential threat of more of these events reaching Ireland and Europe cannot be ignored even though there will still be clusters of years when no tail-ends will reach as far northwards [34].

Future research will focus on identifying the hurricane component of the Irish storm record and in doing so identify what contribution the tail-ends of hurricanes and even hurricanes themselves make to precipitation and wind receipt in Ireland and disentangle these much rarer events from the normal mid-latitude storm signal. 


\section{Acknowledgements}

My thanks to Dr. Siubhán Comer for drawing the maps and to Met Éireann for the hourly wind and rain data.

\section{Author details}

Kieran R. Hickey and Christina Connolly-Johnston

*Address all correspondence to: kieran.hickey@nuigalway.ie

Department of Geography, National University of Ireland, Galway, Rep. of Ireland

\section{References}

[1] Hickey K.R. (2011a) The impact of hurricanes on the weather of Western Europe in Lupo A. (ed) Recent Hurricane Research - Climate, Dynamics and Societal Impacts, InTech, Croatia, p77-84

[2] Hickey K.R. (2011a) The impact of hurricanes on the weather of Western Europe in Lupo A. (ed) Recent Hurricane Research - Climate, Dynamics and Societal Impacts, InTech, Croatia, p77-84

[3] Met Éireann (2012) Exceptional Weather Events Database, Retrieved 31 ${ }^{\text {st }}$ May 2012.

[4] National Oceanic and Atmospheric Administration (NOAA), USA (2012) Atlantic Hurricane Database, Retrieved $6^{\text {th }}$ June 2012.

[5] National Oceanic and Atmospheric Administration (NOAA), USA (2012) Atlantic Hurricane Database, Retrieved $6^{\text {th }}$ June 2012.

[6] Hickey K.R. (2011a) The impact of hurricanes on the weather of Western Europe in Lupo A. (ed) Recent Hurricane Research - Climate, Dynamics and Societal Impacts, InTech, Croatia, p77-84

[7] Met Éireann (2012) Exceptional Weather Events Database, Retrieved 31 ${ }^{\text {st }}$ May 2012.

[8] Bedford R. (2008) Yesterday's weather, Self Published.

[9] Met Éireann (2012) Exceptional Weather Events Database, Retrieved 31 $1^{\text {st }}$ May 2012.

[10] Hickey K.R. (2011b) The hourly gale record from Valentia Observatory, SW Ireland 1874-2008 and some observations on extreme wave heights in the NE Atlantic, Climatic Change, Vol. 106 (3) p483-506.

[11] MacClenahan P., McKenna J., Cooper J.A.G. and O'Kane B. (2001). Identification of highest magnitude coastal storm events over Western Ireland on the basis of wind 
speed and duration thresholds, International Journal of Climatology Vol. 21, p829-842.

[12] Eden P. (2008) Great British weather disasters, London, Continuum.

[13] National Oceanic and Atmospheric Administration (NOAA), USA (2012) Atlantic Hurricane Database, Retrieved $6^{\text {th }}$ June 2012.

[14] Graham E. (2006) 200mm fall in Ireland, Weather, Vol.6 (5), p151.

[15] Met Éireann (1986) Storms cause widespread flooding, Monthly Weather Bulletin, August 1986.

[16] Eden P. (2008) Great British weather disasters, London, Continuum.

[17] Hickey K.R. (2011a) The impact of hurricanes on the weather of Western Europe in Lupo A. (ed) Recent Hurricane Research - Climate, Dynamics and Societal Impacts, InTech, Croatia, p77-84

[18] National Oceanic and Atmospheric Administration (NOAA), USA (2012) Atlantic Hurricane Database, Retrieved $6^{\text {th }}$ June 2012.

[19] Met Éireann (2012) Exceptional Weather Events Database, Retrieved 31 ${ }^{\text {st }}$ May 2012.

[20] Carr P. (1992) The night of the big wind: the story of the legendary big wind of 1839, Ireland's greatest natural disaster, 2nd Edition, Belfast, White Row Press.

[21] Cruickshank J.G., Stephens N. and Symons L.J. (1962) Report of the hurricane in Ireland on Saturday, $16^{\text {th }}$ September 1961, Irish Naturalists Journal, Vol. 14 (1) p4-12.

[22] Kennedy N.D.G. and Kavanagh T. (1968) Bacterial canker (Pseudomonas mors-prunorum) of Sweet Cherries, Irish Journal of Agricultural Research, Vol. 7 (1), p134-136.

[23] Cooper J.A.G., Jackson D.W.T., Navas F., McKenna J. and Malvarez G. (2004) Identifying storm impacts on an embayed, high-energy coastline: some examples from western Ireland, Marine Geology, No. 210, p261-280.

[24] Bedford R. (2008) Yesterday's weather, Self Published.

[25] de Bruijn E.I.F. and Brandsma T. (2000) Rainfall prediction for a flooding event in Ireland caused by the remnants of Hurricane Charley, Journal of Hydrology No. 239, p148-161.

[26] Cawley A.M. and Cunnane C. (2005) A selection of extreme flood events - the Irish experience, Proceedings of the National Hydrology Seminar, Tullamore, Co. Offaly, p14-25.

[27] Mangan B. (1999) Flood risk assessment and communication: the Irish experience, Proceedings of the First RIPARIUS Workshop, Brussels, 27-28 October 1998, p75-86.

[28] MacDonald D.E. and Molyneux J.D. (2002) Rehabilitation of the Upper and Lower Bohernabreena spillways in Tedd P. (ed) Reservoirs in a Changing World, Proceed- 
ings of the 12th Conference of the British Dam Society, Dublin, 4-8 September 2002, p274-285.

[29] Fitzpatrick J. and Bree T. (2001) Flood risk management through reservoir storage and flow control, Proceedings of the National Hydrology Seminar, Tullamore, Co. Offaly, p87-96.

[30] Bhattarani K. and Baigent S. (2009) The hydrological analysis for the final Fingal East Meath flod risk assessment and management study, Proceedings of the Irish National Hydrology Conference, Tullamore, Co. Offaly, p58-67.

[31] Bourke M.C. and Thorpe M. (2005) Rainfall-triggered slope failures in eastern Ireland, Irish Geography, Vol.38 (1), p1-22.

[32] de Bruijn E.I.F. and Brandsma T. (2000) Rainfall prediction for a flooding event in Ireland caused by the remnants of Hurricane Charley, Journal of Hydrology No. 239, p148-161.

[33] Villarini G. and Vecchi G.A. (2012) Twenty-first century projections of North Atlantic tropical storms from CMIP5 models, Nature Climate Change, Vol.2 p604-607.

[34] National Oceanic and Atmospheric Administration (NOAA), USA (2012) Atlantic Hurricane Database, Retrieved $6^{\text {th }}$ June 2012. 